\title{
Analysis and optimization of production technology of the national Kyrgyz beverage Maksym
}

\author{
Irina Bazhenova ${ }^{1, *}$, Elena Chernova $^{2}$, and Tatiana Bazhenova ${ }^{3}$ \\ ${ }^{1}$ Graduate School of Biotechnology and Food Production, Peter the Great St. Petersburg Polytechnic University, St. Petersburg, Russia \\ ${ }^{2}$ Department of Hotel and Restaurant Business, Saint-Petersburg State University of Economics, St. Petersburg, Russia \\ ${ }^{3}$ Institute of secondary vocational education. Peter the Great St. Petersburg Polytechnic University, St. Petersburg, Russia
}

\begin{abstract}
Global migration of populations leads to a widespread of national cuisines, which require adaptation to new consumers. In this regard, it is relevant to change traditional recipes and technologies. Here, we analyzed physical, chemical and organoleptic properties of the national Kyrgyz and Kazakh beverage Maksym. This beverage has a long history, unique properties, and at present is produced only by Shoro. Although being a Kyrgyz signature beverage, when not properly fomulated, it may cause acute intestinal infectious such as salmonellosis, dysentery, and typhoid fever. Our analysis showed that traditional beverage contains $0.9 \mathrm{~g}$ of protein, $4.38 \mathrm{~g}$ of carbohydrates, vitamins: $\mathrm{B} 1-0.08 \mathrm{mg} \%$, B2 $0.1 \mathrm{mg} \%$, PP $-0.4 \mathrm{mg} \%, \mathrm{C}-0.59 \mathrm{gr} \%$ with the useful-energy value of only $27 \mathrm{Kcal}$. This research analyzes variants of barms for the production of national Kyrgyz drink Maksym with different proportion of yeast and lactic-acid bacteria. Traditional Maksym composition and its production technology have been modified. For the produced drink, sediment content, titratable acidity, solids content, ethanol volume, nutritional and energy value, and organoleptic properties were tested.
\end{abstract}

\section{Introduction}

Nowadays there is an increasing number of human disorders caused by unbalanced nutrition. We can categorize obesity, cardio-vascular conditions, cancer, iron deficiency anemia, vitamin deficiency as alimentary-dependent diseases. Therefore, it's essential to follow healthy lifestyle based on balanced dietand provide main nutrients to the body to maintain an active life for many years. In this respect, researchers often pay attention to national food and beverages, which have been known for years and highly regarded by people of these nationalities or inhabitants of certain geographical regions. This research is particularly valuable in modern times, when a variety of national foods is brought to new countries along with human migration. It is also true for Russian Federation where citizens of former Soviet Republics frequently migrate or immigrate, that is why research of national cuisine is of interest.

In this study, we analyzed physicochemical and organoleptic parameters and qualities of national Kyrgyz and Kazakh beverage called Maksym. This beverage is made of ground barley, corn or wheat and it possesses thirst-quenching, restorative and healing properties.

In ancient times, fresh or fermented Maksym was an important edible product of the Kyrgyz. They preferred Maksym to milk or fruit juice to take with them when they had to work hard or to go to pasturelands. The fact is that such drinks made of crops could satisfy thirst and nourish $[1,2]$.
In the $20^{\text {th }}$ century Maksym was produced and consumed only in family circles, that is why there is no main composition and production technology. Also production and consumption of national beverages like Maksym have become less popular due to change in life style and increased urbanization. Nowadays, rraditional food and drinks revival is a modern trend. Today only "Shoro" company (Kyrgyzstan, Bishkek) manufactures Maksym commercially [3].

The main properties of the Maksym are its unique salty-sour taste with a pleasant smell of fried grain and its ability to satisfy thirst fast and long, accompanied with restorative and nurturing qualities. This drink is a source of easily digestible carbohydrates, fiber, minerals and vitamins. The Kyrgyz Scientific Research Institute of obstetrics and pediatrics ran the research of healing properties of the Maksym and its influence on intestinal microbiota regulation $[4,5]$. In these studies, they found that $100 \mathrm{ml}$ of the beverage contains $0.9 \mathrm{~g}$ of protein, $4.38 \mathrm{~g}$ of carbohydrates, vitamins: B1 $-0.08 \mathrm{mg} \%$, B2 $0.1 \mathrm{mg} \%$, PP $-0.4 \mathrm{mg} \%, \mathrm{C}-0.59 \mathrm{gr} \%$, meanwhile the useful-energy value of the drink is only $27 \mathrm{Kcal}[1,4,6]$.

High lactic-acid bacillus content (Lactobacillus plantarum) provides its antagonist activity towards causative agent of gastric ulcer disease Helicobacter pylori [5].

\footnotetext{
* Corresponding author: irinabazhenova@mail.ru
} 


\section{Methods of research}

In this study, we investigate organoleptic, physicochemical (sediment content, content of solid matter, acidity, ethanol volume) and microbiological properties of Maksym using "Shoro" produced "Maksym" as a reference.

Objects of research:

- Barm-yeast and lactic-acid bacteria in different proportions. Different variants of barm contained bakery yeast and freeze-dried leaven of lactic-acid bacteria Lactobacillus;

- Beverage Maksym produced on modified technology with modified composition.

To produce fully fermented, mature beverage, a talkan (a mixture of fried and crushed grains of barley, corn, wheat and millet), rendered fat, water, salt, barm consisted of bakery yeast and lactic-acid bacteria is used.

Organoleptic properties were tested by 10 testers. During the investigation estimated surface appearance, density, color, taste and smell of the national beverage Maksym using 5-point scale with scale spacing of 0.5 points, degustation sheets were developed. Investigated product must meet the requirements of the State Standard Specification R 52409-2005 for non-alcoholic and low-alcoholic products [7].

To run a microbiological research on barms, fixed preparations were made, stained with methyl thionine chloride and examined under microscope Mikmed-5 with immersion optical system. Microphotographs were taken with the magnification of $1600 \mathrm{x}$ using mounted TS-500 camera on the microscope. Photographic processing was implemented by a computer program Levenhuk $[8,9]$.

Weigh fraction of the sediment in the beverage was measured according to the State Standard Specification 8756.9-2016 when the sediment was separated from the product by centrifugation with preheating the product in a water bath. Centrifugation was carried at 1500 revolutions per minute for 20 minand weigh fraction of the sediment was measured by gravimetrical method [10].

Acidity of the Maksym was evaluated by titrimetric method with application of $0.1 \mathrm{~N}$ solution of $\mathrm{NaOH}$ and indicator fenolftalein according to the State Standard Specification 28188-2014 [11].

Solid content was measured with areometer-charmer after having full inversion of the sample with preliminary removal of $\mathrm{CO} 2$ from the drink according to the State Standard Specification 6687.2 [12].

Ethanol volume was evaluated on analyzer of alcohol-containing drinks "Kolos-2". The basic operating principle of the analyzer is to pass ultrasound through the sample and register value of output signals depending on characteristics of alcohol-containing sample.

\section{Research results}

During this investigation, the composition of the main raw material for the beverage preparation was taken from literature as well as from manufactured product composition information. In both cases, the main primary ingradient is talkan - the mixture of grains of corn, barley and oat in certain proportions. While degustating the drink, the group of experts noticed above all an unusual but pleasant taste together with unpleasant density of the drink. Such expert opinion was stipulated by the presence of non-starchy polysaccharide compounds of oat in the drink.

It is essential to note that recipes from literature sources did not suggest to use millet grains as a component of raw material. However, considering ongoing development of millet-based foods in the Russian markets and millet properties [13, 14, 15, 16], it was decided to develop the technology that includes this ingredient. Combination of the traditional and modified mixtures is given in Table 1 .

Table 1. Variants of the composition of the beverage Maksym.

\begin{tabular}{|c|c|c|c|}
\hline \multicolumn{2}{|c|}{ Check sample } & \multicolumn{2}{c|}{ Test sample } \\
\hline components & $\%$ & components & $\%$ \\
\hline Wheat flour & 1.0 & Wheat flour & 1.0 \\
\hline Rendered fat & 3.0 & Rendered fat & 0.2 \\
\hline $\begin{array}{c}\text { Talkan (barley 50 \%, } \\
\text { corn 40\%, oat 10\%) }\end{array}$ & 7.0 & $\begin{array}{c}\text { Talkan (barley } \\
60 \% \text { millet 30\%, } \\
\text { corn 10\%) }\end{array}$ & 7.0 \\
\hline Leaven: bakery yeast & 6.0 & $\begin{array}{c}\text { Leaven: bakery } \\
\text { yeast + lactic-acid } \\
\text { bacteria (55:45) } \\
\text { Fat-free milk }\end{array}$ & 10.0 \\
\hline Drinking water & 83.0 & Drinking water & 82.8 \\
\hline
\end{tabular}

The development of the recipe and production technology of the drink was implicated by different variations of the percentages of the components. After developing each composition variant, there was a degustation and comparative analysis of organoleptic parameters of quality, and the improvements of the composition were made according to the opinions of independent tasters. So, we suggest a new composition with optimal ratio of barley, millet and corn 60:30:10 respectively.

As the result, modified composition of the national drink Maksym is developed and presented in Table 2.

Table 2. Modified composition of the national drink Maksym.

\begin{tabular}{|c|c|}
\hline Primary product & Mass netto, g \\
\hline Wheat flour & 13 \\
\hline Rendered fat & 2 \\
\hline Talkan (barley, millet, corn) & 70 \\
\hline Leaven & 100 \\
\hline Fat-free milk & 25 \\
\hline Drinking water & 800 \\
\hline Outcome & 1000 \\
\hline
\end{tabular}

Developed recipe improved and adapted the product for Russian consumers while maintaining peculiarity, uniqueness and traditional character of the Kyrgyz national drink.

To determine barm composition for talkan fermentation we evaluated different ratios of yeast and lactic-acid bacteria. It was found that fermentation became more intense and the process was finished 2 
hours earlier when lactic-acid bacteria was added. It is necessary to mention that fermentation did not substantially increase ethanol quantity.

During this study we investigated following variants of barm composition with the ratio of yeast to lactic-acid bacteria as 50:50; 55:45; 60:40; 70:30 and without lacticacid bacteria. The results of the research are represented in Table 3.

Table 3. Parameters of the drink according to the proportions of the components of barm.

\begin{tabular}{|l|c|c|c|c|c|}
\hline \multirow{2}{*}{ Parameters } & \multicolumn{5}{|c|}{$\begin{array}{c}\text { Proportion of yeast and lactic-acid } \\
\text { bacteria, \% }\end{array}$} \\
\cline { 2 - 6 } & $50: 50$ & $55: 45$ & $60: 40$ & $70: 30$ & $100: 0$ \\
\hline $\begin{array}{l}\text { Ethanol } \\
\text { volume, \% }\end{array}$ & 0,25 & 0,30 & 0,32 & 0,38 & 0,48 \\
\hline $\begin{array}{l}\text { Fermentation } \\
\text { time, hours }\end{array}$ & 14 & 14 & 15 & 15 & 16 \\
\hline
\end{tabular}

It is established that the most active fermentation happened with the usage of barm where the ratio of the components was 55:45 and 60:40. In a sample with the ratio of yeast and lactic-acid bacteria 50:50 there was excessive sour taste. A test sample with the ratio of the components 70:30 and a sample without lactic-acid bacteria addition showed procrastinated fermentation and unpleasant taste of the product. Without lactic-acid bacteria in a sample, yeast vital activity was decreased dramatically. Thus, fermentation of the product requires combined barm consisted of yeast and lactic-acid bacteria. So, for the production of Maksym it was settled that the barm with ratio of the yeast to lactic-acid bacteria 55:45 was the most favorable.

The results of organoleptic estimation of the modified drink are represented in Table 4.

All tasters distinguished unusually heavy-bodied heterogeneous consistency and peculiar sour corny taste of the product. While consuming the product one could feel slight tingling in the mouth because of low alcohol content and bubbles of carbon dioxide gas. Also, pleasant finish and tonic effect are present.

Comparatively lower score can be likely explained by psychological factors - Maksym is a rather thick beverage, containing grinded fried grain that makes it altogether to be unusual for the most Russian consumers. Nevertheless, thick density of this beverage increases nurturing value, and preserve its nutritionally and biologically valuable substances.

Sediment content after centrifugation and weighing was 17 . $28 \pm 0.65 \%$ for manufactured and $19.33 \pm 0.68 \%$ for prepared beverages, respectively.

Acidity of the beverage Maksym was evaluated by titrimetric method with application of $0.1 \mathrm{n}$ solution of $\mathrm{NaOH}$ and it was $3.61 \pm 0.18 \mathrm{~cm}^{3}$ for manufactured beverage and $4.48 \pm 0.23 \mathrm{~cm}^{3}$ for modified beverage.

Content of solid matter was measured with areometer-charmer and the following results were received- in a check sample it was $4.2 \pm 0.2 \%$, in a test sample $5.04 \pm 0.3 \%$. Thus, the developed sample contains solid matter $20 \%$ more than manufactured sample. It appears to be a positive feature because solid matter contains minerals and fiber which are necessary for proper gastrointestinal system functioning. The usage of millet whole grain allows increasing silicon in the drink. This element was shown to improve skin, hair and nail conditions and preventi atherosclerosis and Alzheimer's disease.

Table 4. The results of organoleptic estimation of Maksym.

\begin{tabular}{|l|c|c|c|c|c|}
\hline \multirow{2}{*}{ Tasters } & \multicolumn{5}{|c|}{ Quality parameters } \\
\cline { 2 - 6 } & $\begin{array}{c}\text { Appeara } \\
\text { nce }\end{array}$ & Colour & $\begin{array}{c}\text { Consiste } \\
\text { ncy }\end{array}$ & Smell & Taste \\
\hline 1 & 4.0 & 4.0 & 4.0 & 4.0 & 3.5 \\
\hline 2 & 4.5 & 5.0 & 5.0 & 4.5 & 4.0 \\
\hline 3 & 4.5 & 3.5 & 4.0 & 4.0 & 4.5 \\
\hline 4 & 4.0 & 3.5 & 3.5 & 4.5 & 4.5 \\
\hline 5 & 4.0 & 4.5 & 3.5 & 4.5 & 3.5 \\
\hline 6 & 5.0 & 4.5 & 4.0 & 4.5 & 4.0 \\
\hline 7 & 4.5 & 4.5 & 4.5 & 4.0 & 4.0 \\
\hline 8 & 4.5 & 4.5 & 4.0 & 4.0 & 3.5 \\
\hline 9 & 4.0 & 4.0 & 4.0 & 4.0 & 4.0 \\
\hline 10 & 4.5 & 4.0 & 4.0 & 4.5 & 4.0 \\
\hline $\begin{array}{l}\text { Average } \\
\text { score }\end{array}$ & 4.35 & 3.75 & 4.05 & 4.25 & 3.95 \\
\hline
\end{tabular}

Estimated feed and energy value of the developed drink is represented in Table 5.

Table 5. Estimated feed and energy value of the developed drink Maksym (per 100g of the product).

\begin{tabular}{|l|c|c|c|c|}
\hline Products & $\begin{array}{c}\text { Protein, } \\
\mathbf{g}\end{array}$ & $\begin{array}{c}\text { Carbohydrates, } \\
\mathbf{g}\end{array}$ & $\begin{array}{c}\text { Fat, } \\
\mathbf{g}\end{array}$ & $\begin{array}{c}\text { Energy } \\
\text { value, } \\
\text { kcal }\end{array}$ \\
\hline Barley & 0.42 & 2.10 & 0.50 & - \\
\hline Corn & 0.10 & 0.50 & 0.04 & - \\
\hline Millet & 0.21 & 1.14 & 0.80 & - \\
\hline $\begin{array}{l}\text { Wheat } \\
\text { flour }\end{array}$ & 0.10 & 0.60 & 0.04 & - \\
\hline $\begin{array}{l}\text { Rendered } \\
\text { fat }\end{array}$ & - & - & 0.02 & - \\
\hline $\begin{array}{l}\text { Fat-free } \\
\text { milk }\end{array}$ & 0.06 & - & 0.02 & - \\
\hline Total & 0.89 & 4.4 & 1.42 & 34 \\
\hline
\end{tabular}

From Table 5 it can be seen that the developed drink possesses rather higher energetic value comparing to manufactured drink (27 Kcal). Inspite this fact, Maksym is a low-calorie product and a source of main nutrient materials. The point is that individual gluten intolerance can become the restriction for its consumption.

\section{Discussion}

Many countries have been producing different fermented drinks and beverages since old times and the most wellknown and widely spread beverages are national fermented milk drinks which are manufactured with the use of different bacteria . including fermented milk drinks (matsoni, katyk, dgugurt etc.), as well as lacticacid and alcohol-fermented beverages (kumiss, airan, kurunga etc.) $[17,18,19]$. 
Vegetal grain-based beverages are less represented than milk-based beverages in national cuisines and they are relatively unknown to consumers from another countries. To manufacture beverages based on plant raw materials different crops including rye, barley, wheat, oat, buckwheat, soya, amaranth, hemp as well as flour, fermented and non-fermented malt, bread, plant supplements, spices are used [18 - 22]. Also, it is essential to mention that different bacteria are used to produce aforementioned drinks, among them yeast of Saccharomyces type (alcoholic fermentation agent), lactic-acid bacteria of Streptococcus, Leuconostoc and Lactobacillus types [23, 24].

Lactic-acid bacteria produce lactic acid and develop certain acidity which is essential for yeast growth. Yeast, for their part, enrich nutrient medium with vitamins and amino acids and stimulate lactic-acid bacteria growth. This process takes place during fermentation of leaven wort, preparation of kefir, and kumiss [25].

Vegetal grain-based drinks have different properties, nourishment and energy values. Beside main nutritional materials, vegetal raw material contains biologically valuable components such as polyunsaturated fatty acids, phospholipids, vitamins, antioxidants, fiber, minerals [26 $-28]$.

The most well-known grain drink in Russia, Belorussia, the Ukrain, Baltic countries is kvass. It has peculiar taste and high thirst-quenching ability due to low sugar, lactic acid and balanced composition of sour/ sweet taste. Along with this, it has high feed value, helps digestion, refreshes and provides main nutrient materials [29-31].

Most kvasses are brewed based on rye, barley, wheat malt, rye flour, leavened bread and dried kvass. Rye malt gives specific taste and smell of the drink, barley malt, in its turn, is used for flour conversion to prepare leavened wort and leavened bread. Among the components of kvass there are alcoholic and lactic-acid fermentation products: carbon dioxide and lactic acid, which give peculiar sour taste and refreshing ability to the beverage, adding that it is also the source of main nutrient materials and easily digestible carbohydrates. Feed value of 1 liter of kvass can fluctuate from 200 to $300 \mathrm{Kcal}$ depending on its sort [30].

In Poland, since $16^{\text {th }}$ century they have been preparing the grain beverage called Podpivok which is manufactured from beer subproducts after first fermentation. Components of this beverage may include yeast, sugar, water, also hop, coffee beans, chicory, barley and another components. Podpivok has slightly bitter taste, it is considered to be a non-alcoholic beverage because it contains only $0.5 \%$ of alcohol. It can be consumed by children and pregnant women as it is recognized to be completely harmless [32].

In Northern Europe the Swiss drink Ovaltin (from ovum-lat. egg; egg and malt were its original ingredients) is also of interest.

In Americas, a number of different corn and canebased beverages are also profuced. produces In Mexico, a beverage named Attolle is prepared from corn flour, milk and vanilla and is linked to Indians Attolle.
In Peru, a beverage Chicha morada produced from violet corn is widely spread.

In Asia, which is well-known by their unusual taste preferences, a beverage called Bori Cha (Korea) - a tea made from fried barley is commonly consumed [19].

Maksym is a fermented product based on mixture of grains and it can attract considerable interest by its ability to provide functional components including fiber, vitamins and minerals. The main properties of the this beverage are its unique salty-sour taste with a pleasant smell of fried grain and its ability to satisfy thirst fast and long along with restorative and nourishing qualities $[5,33]$.

For Russian consumers it is appeared to be quite an unusual product but it has prospects for Russian market.

To adopt Maksym for the Russian market, it is reasonably suggested to use traditional Russian grainsrye, emmer wheat, buckwheat, millet as well as now widely researched and introduced into production, triticale and amaranth [34 - 37].

Consumer property research and organoleptic estimation of Maksym demonstrate that it can be used as a low-calorie dietary product for vegetarians and those who implement weight control, yet it may not be suitable for people with, gluten intolerance. Considering the lack of such beverages in the Russian market, production of Maksym can become really perspective for enterprises of dairy industry and breweries which expect towiden the assortment. With effective advertisement, Maksym could be marketed to a large number of consumers.

\section{Conclusions}

Maksym, as a national Kyrgyz and Kazakh drink, is rather unknown for consumers as it could be found only in a few cafes which specialize in Kazakh cuisine or while visiting traditional Kazakh and Kyrgyz families. Nevertheless, analysis of literature and other recourses as well as the the results of this of this study showed that Maksym, a grain-based beverage, may have multiple advantages for consumers and could be widely marketed. Besides introducing national Kazakh and Kyrgyz food to consumers this beverage is en It is enrichrfwith minerals, polyphenol compounds and other nutrients.

The Maksym fomulation, developed in our study, has heavy-bodied heterogeneous consistency and peculiar sour corny taste with pleasant finish and it gained tonic effect. Sediment content in the drink was $19.33 \pm 0.68 \%$, content of solid matter was $5.04 \pm 0.3 \%$, titrable acidity was $4.48 \pm 0.23 \mathrm{~cm}^{3}$. Solid matter contains minerals, vitamins $\left(\mathrm{B}_{1}, \mathrm{~B}_{2}, \mathrm{PP}, \mathrm{C}\right)$, fiber. The drink influences on intestinal microbiocenosis regulation, exerts acute intestinal infectious germs. High lactic-acid bacillus content (Lactobacillus plantarum) provides its antagonist activity towards causative agent of gastric ulcer disease Helicobacter pylori. In our opinion, with proper advertisement and interest from the manufacturers, developed Maksym formulation could gain consumer's acceptance and popularity as a nourishing, thirstquenching beverage. 


\section{References}

1. T. Borubaev, Kirgizskaya kuhnya (Frunze, Kyrgyzstan, 1982)

2. Maksym Shoro - Shoro Company [Electronic resource] Available at: https://www.shoro.kg/ru/products/drinks/maksyi $\mathrm{m} /$

3. S.T. Kyshtobaeva, T.T. Mamyrbaeva, A.B. Cherikchieva, Central'no-Aziatskij Medicinskij Zhurnal, 2-3 (2003)

4. L.G. Bazhenov, V.M. Bondarenko, E.A. Lykova, D.K. Ogaj, Zh. mikrobiol., epidemiol. i immunobiol., 3 (1997)

5. Kirgizskij nacional'nyj prohladitel'nyj napitok maksym (zharma) [Electronic resource] Available at: https://www.open.kg/aboutkyrgyzstan/culture/kyrgyz-cuisine/drinks-ofkyrgyzstan/35344-kirgizskiy-nacionalnyyprohladitelnyy-napitok-maksym-zharma.html

6. GOST R 52409-2005, Produkciya bezalkogol'nogo i slaboalkogol'nogo proizvodstva, Terminy i opredeleniya (Moskva, Standartinform, 2006)

7. GOST ISO 7218-2015, Mikrobiologiya pishchevyh produktov i kormov dlya zhivotnyh, Obshchie trebovaniya po mikrobiologicheskim issledovaniyam (Moskva, Standartinform, 2016)

8. GOST 30712-2001, Produkty bezalkogol'noj promyshlennosti, Metody mikrobiologicheskogo analiza (Moskva, Standartinform, 2002)

9. GOST 8756.9-2016, Produkty pererabotki fruktov i ovoshchej, Metod opredeleniya osadka (Moskva, Standartinform, 2019)

10. GOST 28188-2014, Napitki bezalkogol'nye, Obshchie tekhnicheskie usloviya (Moskva, Standartinform, 2015)

11. GOST 6687.2-90, Produkciya bezalkogol'noj promyshlennosti, Metody opredeleniya suhih veshchestv (Moskva, IPK Izdatel'stvo standartov, 2002)

12. T.S. Bazhenova, Razrabotka tekhnologii specializirovannyh muchnyh izdelij iz zerna prosa posevnogo (Panicum miliaceum L.) (SanktPeterburg, 2018)

13. T.S. Bazhenova, I.A. Bazhenova, E.V. Chernova, Agronomy Research, 17 (6) (2019)

14. L.A. Astaf'eva, E.S. Sergacheva, V Vserossijskij kongress molodyh uchenyh (2016) [Electronic resource] Available at: https://openbooks.itmo.ru/ru/file/3977/3977.pdf

15. Issoufou Amadou, In Fermented Beverages, 5 (2019)

16. M. Gabaza, et all, J. Food Compos. Anal., 68 (2018)

17. K.V. Kobelev, T.I. Filimonova, O.A. Borisenko, Pivo i napitki, 2 (2011)
18. A. Baschali, E. Tsakalidou, A. Kyriacou, N. Karavasiloglouand, A.-L. Matalas. Nutrition Research Reviews, 30 (1) (2017)

19. S. Carballo Marrero, et all, In Fermented Beverages, 5 (2019)

20. P. Tsafrakidou, et all, Foods, 9 (734) (2020)

21. Z. Kohajdová, Current Developments in Biotechnology and Bioengineering (Elsevier: Amsterdam, The Netherlands, 2017)

22. R. Coda, M. Montemurro, C.G. Rizzello, Yogurt in Health and Disease Prevention (2017)

23. K.V. Kobelev, Nauchnoe obosnovanie $i$ razrabotka innovacionnyh tekhnologij napitkov na zernovoj osnove $i$ ih identifikaciya (Moskva, 2018)

24. S. Wuyts, et all, Curr. Opin. Biotechnol., 61 (2020)

25. M.N. Eliseev, D.S. Lychnikov, L.K. Emel'yanova, T.I. Kuzichkina, Pivo i napitki, 3 (2006)

26. A. Deswal, H.N. Mishra, N.S. Deora, Innovative Technologies in Beverage Processing (2017)

27. S. Sethi, S.K. Tyagi, K. Rahul, Anurag Journal of Food Science and Technology, 53 (2016)

28. S. Kreisz, et all, Gluten-Free Cereal Products and Beverages, 5 (2008)

29. M.N. Eliseev, A.E. Patalaha, S.V. Volkovich, Pivo i napitki, 5 (2008)

30. A.M. Ivashkevich, M.L. Zen'kova, Sovremennyj mekhanizm funkcionirovaniya torgovogo biznesa i turisticheskoj industrii: real'nost' i perspektivy: materialy, III Mezhdunarodnoj nauchnoprakticheskoj konferencii studentov i molodyh uchenyh (2018) [Electronic resource] Available at:

http://edoc.bseu.by:8080/bitstream/edoc/81053/1/ Ivashkevich_A.pdf

31. L.A. Oganesyanc, A.L. Panasyuk, M.V. Gernet, Tekhnologiya bezalkogol'nyh napitkov (SanktPeterburg, Lan', 2018)

32. Sekrety predkov, Napitki «Shoro» zavoevyvayut populyarnost' za rubezhom, Rossijskaya gazeta, 125 (7885) (2019)

33. I.A. Bazhenova, Issledovanie tekhnologicheskih svojstv zerna polby (Triticum dicoccum Schrank.) $i$ razrabotka kulinarnoj produkcii $s$ ego ispol'zovaniem (Sankt-Peterburg, 2004)

34. M. Chavan, Y. Gat, M. Harmalkar, R. Waghmare, LWT - Food Science and Technology, 91 (2018)

35. D. Mridula, M. Sharma, LWT - Food Science and Technology, 62 (1) (2014)

36. D.A. Kodzhegulova, Zh. Estestvennye i tekhnicheskie nauki, 5 (31) (2007)

37. Z. Ciesarová, et all, Fermented Foods in Health and Disease Prevention (2017) 